\title{
"On the Eminent Dr Edward Brown's Travels": A Familial Network of Creation in the Philosophical Transactions
}

\author{
by Anna Wyatt
}

This article explores the authorship of knowledge in the late seventeenth century, with a focus on Dr. Edward Browne's (1644-1708) contributions to the Royal Society and travel literature. An analysis of the manuscript sources and ensuing printed accounts of Browne's 1668-1669 European travels gives rise to three key conclusions: firstly, that correspondence sent to the Society's secretary, Henry Oldenburg (1619-1677), was not always unmediated and was at times edited by agents at home (in this case, Thomas Browne [1605-1682]); secondly, that articles sent directly to Oldenburg by Society agents were also subject to editorial influences other than those of the primary author; and, finally, that the family was a key network of creation, both in articles printed in the Philosophical Transactions and in independent works. Throughout, it will become clear that Edward Browne's publications are not straightforwardly single authored: rather, they are the result of a wide variety of often obscured familial and social interactions.

\section{INTRODUCTION}

Thus from a Foreign Clime rich Merchants come and thus unlade their Rareties at home:

Thus, undergoe an acceptable toyle,

With treasures to inrich their Native Soil.

They for themselves, for others you unfold

A Cargo swoln with Diamonds and gold.

with indefatigable Travels, they

The trading world; the Learned you survey; and for renown with great Columbus vie In subterranean Cosmography. ${ }^{1}$

The above poem, "On the Eminent Dr Edward Brown's Travels," was written by Thomas Flatman (1637-88), a painter and poet, Fellow of the Royal Society, and acquaintance of Dr. Edward Browne (1644-1708). ${ }^{2}$ The comparison of a now little-known traveler-a physician

\footnotetext{
${ }^{1}$ This poem is printed in Thomas Flatman's Poems and Songs (London, 1686). A version of this poem is preserved in the commonplace book of Elizabeth Lyttelton, Edward Browne's sister (Cambridge UL MS 8460, fol. 33).

${ }^{2}$ Flatman was elected to the Royal Society four months after Edward on 30 April 1668, but Edward's journals and the Browne family letters suggest that the Brownes knew Flatman and his kin outside of the confines of the Royal Society: Edward's 1664 journal (BL Sloane MS 1906) mentions that he "had discourse with one Mr Flatman a chirugion" (fol. 46v); in the late 1670s, a postscript from Edward's sister Elizabeth Lyttelton to Edward's wife Henrietta in London asks her "to Put a frame \& glass to the picture for Mr Flatman a very good one" (BL Sloane MS 1847, fol. 224v). Several other references to the Flatman family appear in the family letters of the 1670s.
} 
by trade who made his reputation through his publications (and to no small extent his being the son of Thomas Browne [1605-1682]) — to Christopher Columbus might seem to a modern reader mere flattery, but, while Edward Browne can hardly claim to have discovered the New World, he might rightfully be considered an explorer of "subterranean cosmography."

Edward Browne completed his bachelor of medicine at Trinity College Cambridge in 1663, submitting his dissertation, "Judicium de somniis est Medico utile" ("Of the belief that dreams are useful to the doctor"), on 7 July $1663 .{ }^{4}$ He embarked on his first Continental tour in 1664, taking in Paris before journeying south to Montpellier, Rome, Naples, Padua, and Venice and finally returning home in $1665 .{ }^{5}$ This tour ostensibly supported his medical training; at each location Edward made sure to visit notable anatomical lectures, though this did not preclude a certain amount of cultural sightseeing as well. Once back in England, he proceeded doctor of medicine at Merton College, Oxford, and joined the Royal College of Physicians, where he was to serve as president for the last four years of his life. In early 1668 he was also elected a Fellow of the Royal Society, on whose council he served intermittently from 1670 to $1684 .{ }^{6}$ Flatman's poem lauding him as an indefatigable traveler was prompted by a second Continental tour, which Edward undertook in 1668 to 1669.

Edward first staked his claim as an investigator of "foreign climes" in 1669, when Henry Oldenburg (1619-1677), secretary to the Royal Society, printed "An Extract of a Letter Written by Dr. Edward Brown from Vienna in March 3. 1669. Concerning Two Parhelia's or Mocksuns, Lately Seen in Hungary" in the Philosophical Transactions, the natural philosophy periodical edited by Oldenburg. ${ }^{7}$ This article was followed by three more in the same year, a further three in 1670 , and another in $1674 .{ }^{8}$ Each of these eight articles stemmed

\footnotetext{
3 "Subterranean cosmography" refers to the branch of natural philosophy which investigated topics such as mining and natural springs.

${ }^{4}$ Browne, "Judicium de somniis est Medico utile" (Cambridge, 1663).

${ }^{5}$ For an in-depth overview of Browne's 1664-65 journey, see Robert Iliffe, "Foreign Bodies: Travel, Empire and the Early Royal Society of London. Part 1. Englishmen on Tour," Canadian Journal of History 33 (1998): 357-85. Geoffrey Keynes published part of Edward's 1664-65 tour of the Continent in Journal of a Visit to Paris in the Year 1664 (London: J. Murray, 1923), though this draws upon Edward's first journal alone (BL Sloane MS 1906), which tracks Edward only as far as Paris. A second journal, BL Sloane MS 1886, continues Edward's journey as far as Naples. Letters written home (mostly transcribed and compiled by Thomas Browne and Elizabeth Lyttelton in BL Sloane MS 1868) provide further information on these travels, including details of Edward's return journey.

${ }^{6}$ On 19 December 1667 "Edward Browne, M.D. was proposed candidate by Dr. Croune," and at a meeting of 2 January 1667/8 "Dr. Brown was elected and admitted" (Thomas Birch, The History of the Royal Society of London, 4 vols. [London, 1756-57], 1:227 and 1:234).

${ }^{7}$ Browne, "An Extract of a Letter Written by Dr. Edward Brown from Vienna in March 3. 1669. Concerning Two Parhelia's or Mocksuns, Lately Seen in Hungary,” Philosophical Transactions 47 (1669): 953. The Philosophical Transactions was printed under the imprimatur of the Royal Society, but "printed declarations make it clear that ultimate editorial and financial responsibility for the journal was [Oldenburg's] alone" (Noah Moxham, "Authors, Editors and Newsmongers: Form and Genre in the Philosophical Transactions under Henry Oldenburg," in News Networks in Early Modern Europe, ed. Joad Raymond and Moxham [Leiden: Brill, 2016], 471). The Transactions under Oldenburg "consisted of adapted bits of Oldenburg's correspondence, accounts of books that had come his way ... and reports of experiments performed in the Royal Society and elsewhere" (Aileen Fyfe, Julie McDougall-Waters, and Moxham, "Guest Editorial: 350 Years of Scientific Periodicals," Notes and Records of the Royal Society of London 69 [2015]: 230).

${ }^{8}$ Edward's other Transactions articles are: “An Extract of a Letter Lately Written by Dr Edward Brown to the Publisher, Concerning Damps in the Mines of Hungary and Their Effects," Philosophical Transactions 48 (1669): 965-67; “A Relation Concerning the Quick-Silver Mines in Friuli; Communicated by Dr. Edward Brown; Co Firming as Well the Accompt Formerly Given of That Subject, in Numb 2. of these Transactions, as Enlarging the Same with Some Additions," Philosophical Transactions 54 (1669): 1080-83; “An Accompt from
} 
from Edward's travels on the Continent in 1668-69. In August 1668, Edward set out from Great Yarmouth for Rotterdam. ${ }^{9}$ Neglecting his father's advice not to make "wide excursions," Edward continued to travel through the Low Countries and Germany, arriving at Vienna in November 1668. ${ }^{10}$ From there, Edward made several excursions into Hungary, Italy, and Greece - despite his father's reminder that "no excursion into Pol. Hung. or Turkey adds advantage or reputation unto a scholar" - each time returning to Vienna. ${ }^{11}$ Finally, at the end of 1669, Edward journeyed home via Prague, Dresden, and Hamburg. ${ }^{12}$

All the while, Edward had been collecting information on the natural phenomena of the countries through which he passed, observing features such as mines, natural baths, and lakes. These observations are recorded in his three travel journals, the letters written to his father, and, ultimately, the Philosophical Transactions. ${ }^{13}$ The vast quantity of archival material relating to Edward's journey - his notebooks from this period contain roughly forty thousand words, and the letters a further forty thousand - makes this an ideal case study for asking precisely how travelers' accounts made their way into the Philosophical Transactions. Much has been said of Oldenburg's role as the orchestrator of the Royal Society's information-gathering agenda, stimulating correspondence networks and manipulating agents into discussing each other's works. ${ }^{14}$ However, a thorough case study of material sent to him

the Same Dr. Brown Concerning an Vn-Common Lake, Called the Zirchnitzer-Sea, in Carniola," Philosophical Transactions 54 (1669): 1083-85; "Some Directions and Inquiries with Their Answers, Concerning the Mines, Minerals, Baths, \&c. of Hungary, Transylvania, Austria, and Other Countries Neighbouring to Those," Philosophical Transactions 58 (1670): 1189-96; "An Accompt Given by Doctor Edward Browne, Concerning the Copper-Mine at Herrn-Ground in Hungary," Philosophical Transactions 59 (1670): 1042-1044; "An Accompt Concerning the Baths of Austria and Hungary; as Also Some Stone-Quarries, Talcum Rocks, \&c. in Those Parts: By the Same Hand," Philosophical Transactions 59 (1670): 1044-51; and "Some Queries and Answers, Relating to an Account Given in Numb. 54. by Dr. Edw. Brown, of a Strange Lake in Carniola, Call'd the Zirchnitz-Sea: The Queries Were Made by a Curious Person in France; The Answers Given by the Author of the Said Accompt," Philosophical Transactions 109 (1674): 194-97.

${ }^{9}$ See C. D. van Strien, British Travellers in Holland During the Stuart Period: Edward Browne and John Locke as Tourists in the United Provinces (Leiden: Brill, 1993), for an account of the first part of Edward's journey and of early modern travel in the Netherlands more generally. For an account of the whole 1668-69 voyage, see John D. Spillane, Medical Travellers: Narratives from the Seventeenth, Eighteenth, and Nineteenth Centuries (Oxford: Oxford University Press, 1984), 26-43.

${ }^{10}$ Bodleian Rawlinson D MS 108, 92r.

${ }^{11}$ BL Sloane MS 1847, 166r; this letter is dated 21 December 1668. For a detailed account of Edward Browne's visits to the mining towns in Hungary, see Miklós Kázmér, "Dr. Edward Browne's Visit to the Mining Towns of Lower Hungary in 1669," in Natural Heritage of the Carpathian Basin, ed. J. Kubassek (Érd: Hungarian Geographical Museum, 2004), 193-220.

${ }^{12}$ Eventually Edward published his entire journey in two books: A Brief Account of Some Travels in divers parts of Europe. Viz. Hungaria, Servia, Bulgaria, Macedonia, Thessaly, Austria, Styria, Carinthia, Carniola, and Friuli (London, 1673); and An Account of Several Travels Through a great part of Germany ... (London, 1677). In 1685 and 1687 he published compiled editions of the two works. All of Edward's books were published by Benjamin Tooke of London.

${ }^{13}$ The journals are BL Sloane MSS 1908 (which dates from 8 August 1668 to 9 August 1669, with a break around March and April), 1922 (primarily dating from March 1669, covering Edward's journey into Hungary), and 1905 (dated 23 August 1669-14 December 1669, containing Edward's journey into Greece and his return home). The letters from throughout the journey are mostly collected, alongside later correspondence, in BL Sloane MSS 1911-13, with some letters recorded in Bodleian Rawlinson D MS 108.

${ }^{14}$ See, for instance, Maurizio Gotti, "Scientific Interaction within Henry Oldenburg's Letter Network," Journal of Early Modern Studies 3 (2014): 151-71; Adrian Johns, "Reading and Experiment in the Early Royal Society," in Reading, Society and Politics in Early Modern England, ed. Kevin Sharpe and Steven N. Zwicker (Cambridge: Cambridge University Press, 2003), 244-72; and Marie Boas Hall, "The Royal Society's Role in the Diffusion of Information in the Seventeenth Century (I)," Notes and Records of the Royal Society of London 29 (1975): 173-92. 
from a traveler, including its initial creation and journey into Oldenburg's Philosophical Transactions, has yet to be produced. While the contributions of major figures such as Robert Boyle, Robert Hooke, and Isaac Newton have been well investigated, many of the Society's contributors were more minor figures. ${ }^{15}$ A study of how these 'individuals' interacted with the Society revises our understanding of how the Society came to produce knowledge and encourages us to look beyond conventional models of authorship. In the case of Edward Browne at least, it is a far more complex process than meets the eye.

This article will first investigate the circumstances that precipitated Edward's journey, the expectations that the Royal Society had for its traveling agents, and how it directed them. I will then examine how Edward's foreign correspondence was transmitted to the Royal Society, given that four of Edward's eight articles were published in the Transactions before he even returned home. This section will investigate the role of familial networks to highlight that this correspondence was not simply a direct, unmediated exchange between traveler and Oldenburg. The third section will explore what happens when a traveling agent returns home, since the remaining four Transactions articles were written after Edward's return from the Continent: how did these accounts change in response to the locations and contexts in which they were ultimately produced ${ }^{16}$ I will then begin to explore the precise nature of the relationship between the Royal Society and its foreign agents: though the Royal Society is frequently depicted as a model of cooperative work, Edward's mode of "cooperation" differs from that traditionally associated with the Society. ${ }^{17}$ Finally, I will consider how far we can take the professed work of one man as a truly independent endeavor: the presence of Edward's family at every turn forces us to reconsider the "traditional conception of intellectual change in the period as the work of heroic individuals" and to look instead toward familial models of authorship. ${ }^{18}$

\section{1. "WHITHER TO GOE I AM NOT YET RESOLVED": THE CIRCUMSTANCES OF TRAVELERS' JOURNEYS}

Since its inception in the 1660 s, the Royal Society displayed a preoccupation with providing directions and questions to its investigators and traveling contacts. Following the boom of

\footnotetext{
${ }^{15}$ As Michael Hunter has noted, though "the progress of the Society's work owed most to a small group ... beyond this group of highly active figures there was a larger number of Fellows who played an important part in the Society's work in more limited episodes, who were slightly active over longer periods. ... These Fellows cannot be ignored" ("The Social Basis and Changing Fortunes of an Early Scientific Institution: An Analysis of the Membership of the Royal Society, 1660-1685," Notes and Records of the Royal Society of London 31 (1976): 16).

${ }^{16}$ Percy G. Adams notes that if one "actually makes a voyage and then waits to write about it when he is comfortably seated in his warm study at home, he may add to or alter certain circumstances of the trip and thus be guilty of a kind of falsification" (Travelers and Travel Liars [London: Dover, 1980], 80).

${ }^{17}$ Christopher D'Addario observes that Thomas Sprat's "description points both to the open-endedness of the Society's project and its communal and collective nature" ("Raining Mice and Russian Leather: The Production of Knowledge in the Early Royal Society and Thomas Browne's The Garden of Cyrus," ELH 84 (2017): 16). K. Theodore Hoppen likewise draws attention to the Society's "constant stress on . . . the need for cooperation" ("The Nature of the Early Royal Society: Part II," British Journal for the History of Science 9 (1976): 252. ${ }^{18}$ Michael Hunter, introduction to Archives of the Scientific Revolution: The Formation and Exchange of Ideas in Seventeenth-Century Europe (Woodbridge: Boydell Press, 1998), 16.
} 
travel advice manuals in the late sixteenth and early seventeenth centuries, in which knowledge gathering began to be accepted as a purpose for travel, the Royal Society "took up Bacon's call for agents to search out and gather in knowledge." 19 The Philosophical Transactions published its first list of "enquiries" in issue number five of July 1665, the first year of the journal's printing, and Boyle's well-known "General Heads for a Natural History of a Countrey, Great or Small" appeared in number 11 of April 1666. ${ }^{20}$ These general heads, and others like them, sought "not only [to systematize] knowledge, but also implicitly [to train] the observer in what to record and what sorts of questions to ask in the midst of travel, including, in many cases, explicit attention to natural history." ${ }^{21}$ As Daniel Carey observes, "throughout the first decade of the Society's existence, the minutes record discussions about the need to compile queries" to give to departing travelers: the proliferation of queries within the Transactions — and the Society's enthusiasm for them —influenced the reportage of natural philosophy in the early Royal Society. ${ }^{22}$ This is not to say that the Society was entirely in control of the information it received. At one meeting of April 1665, Robert Moray suggested "that some inquiries might be drawn up to be sent to Mr. Howard's brother concerning observables in Hungary and Turky, whither he was travelling." 23 The Society knew that Howard's brother was abroad, and in response compiled a list of inquiries about his destinations. Consequently, in December 1666, the Philosophical Transactions also printed some "Inquiries for Turky." 24 Robert Illiffe points to a similar instance when, on discovering that Secretary of State Joseph Williamson (1633-1701) was departing for Aachen, Oldenburg "was directed to think of enquiries to which Williamson might stimulate replies." 25 Once more, the queries matched the traveler's intended destination, rather than vice versa, highlighting that much of what the Society ended up discovering through its travelers was stimulated by pragmatism and not just a preselected research agenda. The Society was, in

\footnotetext{
${ }^{19}$ Judy A. Hayden, "Intersections and Cross-Fertilization," in Travel Narratives, the New Science, and Literary Discourse, 1569-1750, ed. Hayden (London: Routledge, 2016), 19. For a discussion of the rise of "scientific" travel and a bibliography of travel advice texts from the sixteenth and seventeenth centuries, see also Luigi Monga, "A Taxonomy of Renaissance Hodeoporics: A Bibliography of Theoretical Texts on 'Methodus Apodemica' (1500-1700)," Annali d'Italianistica 14 (1996): 645-662. Francis Bacon's Parasceve states that knowledge should be "sought out and gathered in (as if by agents and merchants) from all sides" (in The Oxford Francis Bacon, vol. 11, ed. Graham Rees [Oxford: Oxford University Press, 2004], 451).

20 "Enquiries Concerning Agriculture," Philosophical Transactions 5 (1665): 91-94; and Robert Boyle, "General Heads for a Natural History of a Countrey, Great or Small," Philosophical Transactions 11 (1666): 186-89. For more on Boyle's "influential" heads, see Michael Hunter, "Robert Boyle and the Early Royal Society: A Reciprocal Exchange in the Making of Baconian Science," British Journal for the History of Science 40 (2007): $1-23$.

${ }^{21}$ Daniel Carey, “Inquiries, Heads, and Directions: Orienting Early Modern Travel,” in Hayden, Travel Narratives, 37.

${ }^{22}$ Ibid., 45. For more on the heads and inquiries, see Adam Fox, "Printed Questionnaires, Research Networks, and the Discovery of the British Isles, 1650-1800," Historical Journal 53 (2010): 593-621.

${ }^{23}$ Birch, History of the Royal Society, 2:40-41. Charles Howard (1630-1713) was a fellow of the Royal Society by 1665 , but his brother, Henry Howard, sixth Duke of Norfolk (1628-1684), was not a fellow until 1666, making it likely that this instance refers to Henry being abroad. Edward Browne records many sociable activities with the Howards throughout his journal of 1663-64. He also refers to Henry Howard on several occasions in correspondence from his 1668-69 travels.

24 "Inquiries for Turky," Philosophical Transactions 20 (1666): 360-62.

${ }^{25}$ Iliffe, "Foreign Bodies: Travel, Empire and the Early Royal Society of London. Part 2. The Land of Experimental Knowledge,” Canadian Journal of History 34 (1999): 42.
} 
short, aiming to capitalize on, and simultaneously direct, self-funding travelers' observations abroad.

The lists of inquiries, however, did not serve the Society alone. Travel manuals that began to accept research as a reasonable motive for travel usually also highlighted that "if you should travell but to travell, or to say you had travelled, certainly you should prove a pilgrim, no more." 26 To be accepted, travel had to have a purpose, particularly in an era in which the Grand Tour was still a reasonably new phenomenon outside of noble and courtly circles. ${ }^{27}$ Hermanus Kirchner's preface to Thomas Coryat's Crudities, though, poses a dilemma: he says to his imagined reader that "I see your feete to itch, and that the very notion of your bodies doe argue an inclination to travel." ${ }^{28}$ Edward was just the kind of reader that Kirchner envisaged. One of Thomas's letters to Edward at Paris, during his first tour in 1664, requested his return. This letter put Edward "into Dolefull dumps and spoiled all the fine Chymara's and Geographicall Ideas that I had formed in my brain of seeing spaine, Italy, Germany, and I cannot tell how many countreys and people." 29 Clearly wanderlust affected early modern people, despite being considered an insufficient motivation for travel. Over four years later, in October 1668, two months after leaving home once again and already in Frankfurt, Edward admitted to his father that he was still "not yet resolved" on where to go ${ }^{30}$ Edward had a taste for travel and admits - in familial letters at least - to high conceits and chimeras; he was not simply abroad for the educational purposes lauded by travel manuals. The fact, then, that the Royal Society began to provide purposeful directions for travelers from around 1666 offered Edward a way to sanction his second Continental tour. The Society's extensive lists of inquiries into foreign climes not only provided a chance for them to direct travelers and gather accounts but also gave travelers the opportunity to validate their own journeys - even if they arose initially from fine chimeras - by offering an imprimatur endorsed by a charter approved by the king himself.

In a letter to Edward at Vienna dated 2 December 1668, Thomas Browne suggested that his son "observe anything in order to the Royall Societie." 31 In a letter to his father of 3/13 December - written before he had received that letter from Thomas-Edward informed Thomas that he had "wrote to Mr Oldenberg secretary to ye Royall Society to know what he

\footnotetext{
${ }^{26}$ Philip Sidney, Profitable Instructions: Describing what speciall observations are to be taken by Travellers in all Nations, States and Countries; pleasant and Profitable. By the three much admired, Robert, late Earle of Essex. Sir Philip Sidney, and, Secretary Davison (London, 1633), 77-78.

${ }^{27}$ Although early "Grand Tours" were not the "fully-fledged, art-focused, eighteenth-century form" that we are familiar with, Michael G. Brennan notes that by the 1630s "an extended period of travel on the continent was no longer the exclusive prerogative of either the court elite or the spectacularly wealthy" (Edward Chaney and Timothy Wilks, The Jacobean Grand Tour: Early Stuart Travellers in Europe [London: Tauris, 2014], 34; and Brennan, The Origins of the Grand Tour: The Travels of Robert Montagu, Lord Mandeville, 1649-1654; William Hammon, 1655-1658; Banaster Maynard, 1660-1663 [London: Hakluyt Society, 2004], 32). For more on the origins of the Grand Tour, see John Towner, "The Grand Tour: A Key Phase in the History of Tourism," Annals of Tourism Research 12 (1985): 297-333.

${ }^{28}$ Kirchner, "An Oration . . . concerning this subject: that young men ought to travell into forraine countryes, and all those that desire the praise of learning and atchieving worthy actions both at home and abroad," in Coryat's Crudities (London, 1611), C7.

${ }^{29}$ BL Sloane MS 1906, 116v-117r. Despite Thomas's request, Edward's early travels continued well beyond this June 1664 entry.

${ }^{30}$ BL Sloane MSS 1911-13, 4r.

${ }^{31}$ Bodleian Rawlinson D MS 108, 95r.
} 
or they please to commande me in these parts." 32 Apparently independently of one another, father and son had both pinpointed the Royal Society as a validating body for Edward's journeys. Though Edward had had no direct communication with Oldenburg before he sent this letter, and he appears to have had no set itinerary upon departing England, there are early indications that he intended to use this trip to investigate on behalf of the Society, or perhaps that he intended to use the Society's queries to validate his trip. On 13 August 1668, just after Edward had left Norwich, Thomas told him that Edward's sister "Betty \& I searched for the transactions, butt could only find the lesser part wherin that discours is not." 33 Though the letter that prompted this response is missing, the discourse that Edward requested may have been one of the many lists of inquiries printed in the Philosophical Transactions. ${ }^{34}$ In December Oldenburg replied to Edward with a list of queries concerning the mines of Austria, Hungary, and Transylvania, which was also sent to one Marcus Marci to no response. ${ }^{35}$ Perhaps not coincidentally, in February 1669 Edward recalled reading the "description of the mines by Liege in the transactions"; this particular recollection may well have been prompted by the Society's requests, whether Edward read that account before or after he left for the continent. ${ }^{36}$ In this way, Edward's relationship to the Society shaped his travels, both giving him geographical direction and offering an imprimatur to an otherwise unallied journey. ${ }^{37}$ The Royal Society's aims to systematize travel had inadvertently validated Edward's wanderlust by transforming it into directed investigation.

Edward's method of co-option into the Society's service, however, differs from that of Henry Howard and Joseph Williamson: even though Edward was a member of the Society by the time he left on his travels, he himself instigated the correspondence with Oldenburg. Where the Society heard tell of Howard's and Williamson's travels and consequently enlisted them for service, Edward put himself into the line of duty. What's more, the Society had actually directed Edward to investigate phenomena that he had shown an interest in as early as 1662, when he and his brother Thomas took a tour of England. In the record of this tour, Edward frequently recalls visiting subterraneous points of interest, such as the mines by Bradwell, where he "tooke some notice of the lead mines of which there are a vast number,"

\footnotetext{
${ }^{32}$ BL Sloane MSS 1911-13, 10r.

${ }^{33}$ BL Sloane MS 1847, 233r.

${ }^{34}$ By August 1668, the Philosophical Transactions had printed fourteen articles of inquiries and directions.

35 Oldenburg to Edward Browne, 18 December 1668, in The Correspondence of Henry Oldenburg, ed. A. Rupert Hall and Marie Boas Hall, vol. 5 (Madison: University of Wisconsin Press, 1968), 261. Royal Society

EL/B1/132, a letter from Edward to Oldenburg, acknowledges receipt of the queries. The inquiries sent to Edward requested general information on "mineralls springs, warm baths, earths, quarries, [and] metalls" in "Hungaria, Austria \&c.," and offered more specific inquiries into antimony, vitriol, gold and silver ore, salt pits, quicksilver, copper mines, and methods of extraction used by the workers.

${ }^{36}$ BL Sloane MSS 1911-13, 13r. Edward's letter attributes this article to Paul Neile, though it was attributed in the Transactions to Robert Moray. Moray produced several articles on the mines at Liege for the Transactions, and Edward may be referring to "Of the Mineral of Liege, Yielding Both Brimstone and Vitriol, and the Way of Extracting Them Out of It, Used at Liege," Philosophical Transactions 3 (1665): 45-46; or to "An Account How Adits \& Mines are Wrought at Liege without Air-Shafts, Communicated by Sir Robert Moray," Philosophical Transactions 5 (1665): 79-82.

${ }^{37}$ Jason H. Pearl notes that "the relationship was reciprocal in that the Society's Fellows, most of them gentlemen, could offer many travelers - merchants, sailors, soldiers, buccaneers - a level of social prestige that would have been otherwise unobtainable" ("Geography and Authority in the Royal Society's Instructions for Travelers," in Hayden, Travel Narratives, 77). I propose that this reciprocity extends to "wanderers" as much as to merchants.
} 
and the thermal springs of Buxton, where, upon putting his "hand into the water [Edward] conceaved one finger to freeze til the other could not not indure the heat of the hot boyling spring just by it." ${ }^{38}$ In 1669, Edward found himself in a region that the Society had already identified as an area for subterraneous investigations. ${ }^{39}$ The Society's consequent employment of Edward thus allowed him to pursue preexisting interests. As well as supporting the notion that the Society acted as a legitimizing body for otherwise undirected travels, this highlights the interdependence, or "partnership," of Society and traveler: it is not simply that the traveler required the Society's approval or direction to avoid his travels becoming mere pilgrimage, but that the Society relied on cooperating members to offer up their services. ${ }^{40}$ Edward was evidently in Oldenburg's blind spot when he left for Rotterdam, being a new member of the Society and of no particular social status; had Edward not offered his services to the Society and informed them of his travels, much of the content he ended up publishing in the Philosophical Transactions would have been either heavily delayed or omitted altogether. While Oldenburg was the mainspring of much Society correspondence, he relied on new investigators approaching him as well as on existing networks of correspondence.

\section{2. “AS I PROCEED I SHALL WRITE”: FOREIGN CORRESPONDENCE}

Despite the fact that Edward put himself into contact with Oldenburg directly in December 1668 , advertising himself as "ready to give a faithfull account to any inquiries," the correspondence which followed largely went through the hands of his father before it reached Oldenburg. ${ }^{41}$ This immediately complicates what might otherwise seem to be a simple exchange of information from agent to correspondent.

Having received some inquiries from the Royal Society into the buildup of noxious gases in mines, known as "damps," in December 1668, Edward diligently collected information that he considered useful throughout his travels. ${ }^{42}$ On 1 April 1669, Edward wrote to his father with some comments on the mines in Schemnitz (Banská Štiavnica in

\footnotetext{
${ }^{38}$ Sloane MS 1900, 50r and 44v. It is not absolutely clear who the author of this relation is: I have ascribed it here to Edward Browne in the absence of any material evidence to the contrary and because it is preserved in Edward's hand among his own notes. This particular experiment also bears some affinity to Edward's 1664 trip to the Grotto del Cane at Naples, where "much taken with this curiosity I went into the grot myselfe and finding no inconvenience from those poysonous exhalations ether by standing or putting my hand to the place where the dog died I was about to put my head to it also, when to the hindrance of my satisfaction in this point, my companions and the Guid furiously tore mee out of the grot, and I think without some persuasions would have throwne mee into the lake" (Sloane MS 1868, 24r). However, Geoffrey Keynes and Reid Barbour repeat Simon Wilkin's ascription of the Derbyshire relation to Thomas Jr.: it does seem to be a fair (but working) copy, which makes its authorship ambiguous, and the author names neither himself nor his primary companion. If this relation is indeed by Thomas Jr., then it offers a fascinating avenue for further research into collaborative or shared familial authorship. See Keynes, The Works of Sir Thomas Browne, vol. 4 (London: Faber \& Faber, 1964), 2; Barbour, Sir Thomas Browne: A Life (Oxford: Oxford University Press, 2013), 377; and Wilkin, Sir Thomas Browne's Works, vol. 1 (London, 1835), 22.

${ }^{39}$ In addition to the unanswered inquiries sent to Marcus Marci, Boyle had printed "Articles of Inquiries Touching Mines" in Philosophical Transactions 19 (1666): 330-43; and Thomas Henshaw and Abraham Hill had specifically asked "what is observable ... as to Minerals, Springs, Warm Baths, Earths, Quarries, Mettals, $\& s "$ in the "Inquiries for Hungary and Transylvania" in Philosophical Transactions 25 (1667): 467.

${ }^{40}$ Pearl, "Geography and Authority," 77.

${ }^{41}$ Royal Society EL/B1/131.

${ }^{42}$ Royal Society EL/B1/132.
} 
modern Slovakia), recalling that in one mine he had "passed quite under a greate hill, and came out on the other side" and relating the story of five men killed by a damp in another. ${ }^{43} \mathrm{~A}$ letter shortly after this one, dated 8/18 April 1669, reports to Thomas Browne that

I have many things to say concerning damps and other particulars in their inquiries of which I will set downe every post somewhat for what is at Norwich I count safe and your goodnesse and indulgence will looke favorably upon my observations and helpe me to range them methodically against the time that they must be looked upon by more severe eyes. ${ }^{44}$

A further letter of 28 April 1669 reminds Thomas that most of the previous letter "was concerning dampes in mines which account may be by it selfe if you thinke fit $\mathrm{Sr}$ communicated to Mr Oldenburg." ${ }^{45}$ Each of these three letters, written throughout April, partially addresses the Society's question of "what damps are met with" in mines, culminating in what Edward describes as an account written explicitly for the Society.

However, Thomas Browne did not send that account as it was. Instead, in a letter to Edward of 25 June 1669, he tells him that "I sent your observations of damps in the mines of Hung. to the R.S. adding some particulars out of the other letters \& the firing of Chremnitz mine by a boy." 46 Thomas took some creative license with his son's letters, splicing them together and adding stories he considered relevant-including, for instance, Edward's story that he "passed quite under a greate hill"- before sending them on to Oldenburg, who in turn printed Thomas's version of the account in the Philosophical Transactions. ${ }^{47}$ This rather complicates any notion that the letter that ended up with Oldenburg - and, ultimately, in the Transactions - was actually written by our traveler. The original letter preserved in the Royal Society archives is in a scribal hand unlike either Edward's or Thomas's, suggesting that Thomas not only rewrote Edward's letters into a single coherent account but also to an extent anonymized them. Thomas's spidery handwriting would no doubt have been distinctive, even to Oldenburg who received so much correspondence, and the scribal copying of the finished article masks Thomas's authorial intervention. Furthermore, the letter Thomas sent Oldenburg is dated "Vienna April 20 Styl novo 1669" and signed "Edward Browne"; this letter thus claims to be unadulterated, signed and dated as though it were Edward's original, and contains no reference to its being doctored by Thomas Browne. In this case, the purported foreign correspondence is not foreign correspondence but an amalgamation of several letters, including those addressed to family rather than to the Society. The fact that the copy Oldenburg received is not in any recognizable Browne family hand highlights the need for

\footnotetext{
${ }^{43}$ BL Sloane MSS 1911-13, 19r-20r.

${ }^{44}$ Ibid., $24 \mathrm{r}$.

45 Ibid., 27r.

${ }^{46}$ Bodleian Rawlinson D MS 108, 48r.

${ }^{47}$ Edward Browne, "Damps in the Mines of Hungary," 966. The account was read to the Society on 3 June 1669. Thomas Browne's instinct to add stories to Edward's account somewhat undermines the claim that the Society's queries "alone do most of the work, ostensibly leaving little room for tall tales" (Pearl, "Geography and Authority," 73). The fact that the final account reflects no single letter, but rather includes information scattered across Edward's archives, supports the notion that Thomas created this account out of Edward's letters.
} 
scholars to question the provenance of letters, even when they are professed to be originals of a certain date. In this instance, Thomas actively admitted to changing Edward's letterthough he did not say as much to the Society_-but there are undoubtedly many more instances throughout the Society's archives and beyond where letters are not the product of a single author but compilations created by associates at home or elsewhere. ${ }^{48}$

Other issues concerning liaison present themselves across Edward's foreign correspondence destined for the Royal Society, including messengers' capacity to delay accounts. An account of the quicksilver mines in Friuli, sent by Edward in June 1669, was not read to the Society until 28 October. Thomas Browne was once more responsible for passing this account on to the Society, and he offered a letter of apology when he finally sent it, stating that his son had told him he hoped to be home before Michaelmas and so would deliver the account himself. No extant letter explicitly states this return date, though Edward's postscript to his mother of 5 July 1669 does state that he is "now returning" and expected to be in Norwich in October. ${ }^{49}$ This corroborates Thomas's excuse for his delayed sending of the letter. However, there is a complication: in July, or shortly before, Edward sent his father another account, this time about the Zirchnitzer sea in Carniola (Lake Cerknika in modern Slovenia). Edward visited Lake Cerknika just one day before he visited the Friuli quicksilver mines, and notes in a letter of 11/21 July that his last letter "enclosed an account of Zirchnitz" which could be sent to the Society if Thomas approved. ${ }^{50}$ Thomas did indeed send this account, Oldenburg writing a letter of thanks to Edward on 24 July. ${ }^{51}$

However, Edward sent the letter of the quicksilver mines before 26 June, when he told his father that his last letter "was concerning the quicksilver mines," so that Thomas should have had both letters around the same time. ${ }^{52}$ Between these dates, nothing in the extant correspondence documents a change in itinerary for Edward, which forces us to ask why Thomas sent one account but not the other. If he received the account of the quicksilver mines before the account of Cerknika, thinking that Edward would be back before October, why did he send the Cerknika account? If he had received the account of Cerknika before the account of the quicksilver mines, and had sent it regardless of Edward's projected itinerary, then why did he not send the quicksilver account? There are many moving parts to these exchanges, made no simpler by the unreliable pace of a trans-European postal system, but it must have become clear to Thomas at some time much earlier than the end of October that Edward was not going to be home when he initially thought. Whether he simply forgot about the account that he had not sent, or whether he purposely delayed it, the outcome is the same: because

\footnotetext{
${ }^{48}$ While James Daybell notes that "various parties might be involved in the process of composing correspondence, in addition to the person in whose name the letter was sent: secretaries, scribes, scriveners and clerks," these are all essentially professional copyists (The Material Letter in Early Modern England:

Manuscript Letters and the Culture and Practices of Letter-Writing [New York: Palgrave Macmillan, 2012], 74). Andrew Gordon draws attention to the problem of "counterfeit correspondence," made possible by a dependency on the copyist culture that Daybell identifies ("Material Fictions: Counterfeit Correspondence and the Culture of Copying in Early Modern England," in Cultures of Correspondence in Early Modern Britain, ed. Daybell and Gordon [Philadelphia: University of Pennsylvania Press, 2016], 85-109). Gordon's notion of "material fictions" is a useful way to understand the kind of editing that Thomas Browne engages in here.

${ }^{49}$ BL Sloane MSS 1911-13, 40v.

${ }^{50}$ Edward records his visit to these two locations in BL Sloane MS $1905,79 \mathrm{v}-80 \mathrm{r}$; he mentions that he sent an account of Cerknika in BL Sloane MSS 1911-13, 42r.

${ }^{51}$ Royal Society LBO/3, fol. 156.

52 BL Sloane MSS 1911-13, 38r.
} 
Edward used a mediator, rather than sending materials directly to Oldenburg, the flow of information was stunted. ${ }^{53}$ It is also worth mentioning that both of these accounts are written in the same scribal hand as the account of the damps, which Thomas had edited. The account about the Friuli quicksilver mines also includes information recorded by Edward in a later letter, leaving its provenance open to suspicion. ${ }^{54}$ We have already seen Thomas import information from other letters into Edward's accounts for the Society, and it is not impossible that he did it again here. Once again, the mediated nature of Edward's correspondence throws into question the singular authority of the accounts which were ultimately printed in the Philosophical Transactions.

The final example of the complexity of Edward's foreign correspondence concerns the first account that was sent to the Society by Thomas Browne. The letter, addressed by Edward to his father and later sent by Thomas Browne to Oldenburg, includes Edward's transcription of an account of two parhelia seen in Hungary written by one "Father Miche a Jesuit.".55 Edward included in his letter his own drawing of the phenomenon, which is also preserved in the Royal Society's letter books alongside a secondary transcription of Edward's letter. ${ }^{56}$ The majority of the original letter is in Edward's hand: where the later accounts of the damps, quicksilver mines, and Lake Cerknika are all copied (or compiled) back in England and written out by a scribe, Thomas sent the original of this letter to Oldenburg. He did, however, make some changes.

Alongside Edward's letter, Thomas included a shorter framing letter. ${ }^{57}$ Writing in his own hand, Thomas dates it "March 3 Stylo Novo 1668"- - the same date as the full letter-and signs off as "Edward Browne." ${ }^{58}$ Essentially, this addendum is compiled from parts of the letter included with it, simplified to advertise the key topic: the parhelia. ${ }^{59}$ As we may suspect of some of the other accounts, this was not Edward's original but is rather excerpted by Thomas and presented as the original. This preface leads into Edward's own autograph letter. Edward's text begins by telling his father that "I wrote to you three dayes since in which I sent you an account of the Baths at Baden." 60 This much is corroborated by Sloane MSS

\footnotetext{
${ }^{53}$ Even if the delay was accidental, is it no less meaningful. As Howard Marchitello highlights, "accidents abound, and they are meaningful precisely because they are uncaused" (Narrative and Meaning in Early Modern England [Cambridge: Cambridge University Press], 45).

${ }^{54}$ The account finishes by noting that "I passed over Swartzenberg or the black mountaine from whence I descended ten miles in a Rocky countrye, and farre more stony then the Crau or campus Lapidosus in Provence and so to Aidoshini and Goritia. and leaving the Sclavonian behind, entered into the Lingua Fullana" (Royal Society EL/B1/138). A letter to Thomas of 26 June tells us that Edward "passed over the hill Swartenberg or the black mountaine. and descended about 10 English through a stony rocky country worse then the Crau or Campny lapidosus in Provence to a little towne called Adoshini. the next day I dined ${ }^{\wedge} \mathrm{at}^{\wedge}{ }^{\wedge}$ Goritia. . . . in this countey they speake la Langua Fullana" (BL Sloane MSS 1911-13, 38r).

${ }^{55}$ Royal Society EL/B1/134. A parhelion is "a bright spot in the sky, often associated with a solar halo and often occurring in pairs on either side of the sun (or occasionally above and below it), caused by the reflection of sunlight on ice crystals in the atmosphere; a mock sun, a sun dog" (OED Online, s.v. "parhelion, n.").

${ }^{56}$ Royal Society LBO/3, fols. 34-35. Edward's original drawing is inserted into the letter book between the two pages of the transcription of his letter.

${ }_{57}^{57}$ Royal Society EL/B1/133.

${ }^{58}$ Ibid.

59 "I receaved the account of the 2 parelia (seen in Hungaria, the one last easter day the other the 30 of January late) from a learned person father Miche a Jesuit who lives at Presburg butt is now in this citty. together with his complement to the emperour. You may, if you please, have the figure better drawne then I have done it \& to send it to my honor'd friend Mr Oldenburg" (ibid.).

${ }^{60}$ Royal Society EL/B1/134.
} 
1911-13, which includes Edward's letter of 28 February about the baths. However, Thomas Browne's hand intervenes in the Royal Society letter, literally overwriting Edward's hand so that the original line about the baths is now exceedingly difficult to read. The text that Thomas inserts is hardly surreptitious and actively serves to obscure Edward's "sent you the account of the Baths at Baden." 61 Though Thomas's own handwriting is also difficult to decipher here, even by Thomas Browne's paleographical standards, it almost certainly does not mention the baths. Indeed, it is not what he is writing, but what he is obscuring, that is of interest: even though we can still just about make out Edward's original words, the recipient is clearly meant to read Thomas's hand instead of straining to see Edward's hidden hand. An account of the baths at Baden - which will be discussed in more detail in the following section-was printed once Edward had returned home. The basis for that account is the letter that Edward mentions here, which Thomas obscures. It is as though Thomas knew that the Society would want the account of the baths and, knowing he had it, would request it. Instead, Thomas essentially seems to hide the fact that he had the account, perhaps in order to allow Edward to "range [the accounts] methodically." 62 Clearly, scribal copying was not the only way to edit a correspondent's voice; here, the original recipient of the letter literally overwrites it to serve his own purposes.

Thomas makes one other notable change to Edward's letter before sending it to the Society. Just before transcribing Father Miche's account, Edward tells his father that "the figure if you please may be sent to Mr Oldenburg secretary to the Royall Society, or my sister may draw another more exactly like rainbowes and sende it them." 63 A letter of 2 December 1668 from Thomas to Edward mentions that "beside limning Bet. practiseth washing black and colours"; a letter from Edward to his sister of 9 March 1669 tells her that "I want you with me to draw me abundance of fine pictures of strange things"; another letter of 5 July admits that "though I make many journeys yet I am confident that your pen and pencill are greater travellers, how many fine plaines doe they passe over and how many hills, woods, seas, doe they designe?" 64 In short, Edward's sister Elizabeth Lyttelton —or "Betty" — was a fine draughtsman, and his original letter to the Society suggests that her picture of the parhelia would serve as a better resource than his own. ${ }^{65}$ Once more, Thomas overwrites Edward's words. This time, he adds the grammatically questionable "I pray Sr seen \& sent," crossing out the line that suggests that Lyttelton might redraw Edward's sketch. ${ }^{66}$ Why Thomas

\footnotetext{
${ }^{61}$ Ibid.

${ }^{62}$ BL Sloane MSS 1911-13, 24r. The letter from which this quotation is taken was sent on 18 April 1669, after both the account of the baths and the account of the parhelia, so this alone does not account for Thomas's interventions, but it does outline the role that Thomas Browne took—and Edward envisioned him taking -in shaping Edward's publications.

${ }^{63}$ Royal Society EL/B1/134.

${ }^{64}$ Bodleian Rawlinson D MS 108, 94v; and BL Sloane MSS 1911-13, 16r and 40v-41r.

${ }^{65}$ For another instance of female draughtsmen engaging with scientific inquiry, see Anna Marie Roos, "The Art of Science: A 'Rediscovery' of the Lister Copperplate," Notes and Records of the Royal Society of London 66 (2012): 19-40. Roos notes that Martin Lister "taught his two daughters, Susanna (bap. 1670, d. 1738) and Anna (1671-ca. 1695-1704), how to limn and engrave images," pointing to "the important and often hidden role of family connections, artisanal work, aesthetic practice and empirical perception in the transformation of a field specimen into an object of scientific enquiry in the early modern era" (20 and 34).

${ }^{66}$ The sentence with Thomas's additions reads in full: “the figure I pray Sr seen \& sent to Mr Oldenburg, secretary to the Royall Society, like rainbowes and sende it them" (Royal Society EL/B1/134).
} 
thought this particular mention of Lyttelton's drawing skill was not appropriate to the Society is not clear.

However, it is clear that he did not simply think her drawing amateurish. British Library Add. MS 5233 includes Lyttelton's own copy of the image of the parhelia. ${ }^{67}$ Though drawn on unfolded paper, Lyttelton adds a dividing line down the center of the page to create the format of a page fold, imitating Edward's original. The text and its positioning are precisely consistent between Edward's original and Lyttelton's copy, but the lines on Lyttelton's copy are cleaner, the coloring more vibrant and exact, and the images of the suns themselves more detailed, with Lyttelton copying the face in Edward's sun with extra care and precision. ${ }^{68}$ Lyttelton obviously made this copy with Edward's original in front of her, perhaps thinking that her father would send it on to the Society. For whatever reason, though, this version stayed with Browne's papers in Norwich. ${ }^{69}$ Seemingly, Edward used it once he returned; there is a second copy of the parhelia image in Add. MS 5233, this time in Edward's hand. This seems to be a copy either of the original or of Lyttelton's copy, because it is unfolded - and is therefore not the original, never having been posted - and unadorned, lacking color, clouds, or faces in the suns. ${ }^{70}$ The picture contains just enough detail to support the accompanying text; it is a factual record rather than an aesthetic one.

Though the account of the parhelia is largely in Edward's own handwriting it still faced significant redaction and editing before being sent to Oldenburg, once more complicating a notion of direct transmission from agent to Society. Furthermore, the reference to his sister and the fact that she might have contributed something to this exchange of knowledge invite us to consider a communication network which not only includes sender and recipient but encompasses several other cooperating agents along the way. Though the letter and the image are attributed to just one person, Edward was not the only author involved in any of the accounts sent during his time abroad. Thomas Browne compiled pieces of various letters to form one coherent account; a scribe copied accounts sent by Edward and - certainly on one occasion at least - edited by Thomas; material was withheld from the Society by Thomas; and Edward's sister was involved in creating a more precise record of visual resources. As these cases attest, heeding the specific provenance of letters and accounts draws attention to their complex histories of creation: the single-author attribution system largely obscures the multiplicity of voices present in any given text's creation. Though by the end of the seventeenth century travelers were no longer exclusively believed to "lie by authority," that did not preclude networks at home-who were responsible for the safe delivery of information - from editing and redacting the words of the traveler. ${ }^{71}$

\footnotetext{
${ }^{67}$ BL Add. MS 5233, 32v.

${ }^{68}$ See appendix A for Lyttelton's copy and Edward's original. The account that accompanies Lyttelton's version is in Thomas Browne's hand, though the text surrounding the image is in Lyttelton's autograph.

${ }^{69}$ This image is now bound with a collection of other drawings, many of which represent places visited during Edward's travels and which may also have been drawn by Lyttelton. During Edward's first Continental journey Lyttelton and her father shared the work of copying his letters into their own letter book at home. Many of the images in Add. MS 5233 contain Thomas Browne's autograph copying Edward's text, suggesting that they were created while Edward was still on the Continent.

${ }^{70}$ See appendix B for Edward's copy.

${ }^{71}$ For the history of the maxim that "travellers . . . may lie by authority," see Morris Palmer Tilley, Dictionary of the Proverbs in England in the Sixteenth and Seventeenth Century (Ann Arbor: University of Michigan Press, 1950), P28, p. 520. For other discussions of the traveler as liar, see Adams, Travelers and Travel Liars; Adams,
} 


\section{3. "YOUR HAPPY RETURNE”: HOME CORRESPONDENCE}

Edward finally returned home to Norwich in December 1669, having spent a year and a quarter traveling the lesser-known parts of Europe. ${ }^{72}$ Throughout his extensive journeying Edward had collected a vast amount of information across his journals, notebooks, and correspondence, much of which was naturally of interest to the Royal Society. After his return to Norwich, where Edward could easily correspond directly with the Society, he relieved his father of the responsibility of sending accounts of foreign natural phenomena. Much of the material in accounts written after Edward's return follows letters sent to his father very closely.

One such account is that of the "Baths of Austria and Hungary; as Also Some StoneQuarries, Talcum Rocks, \&c. in Those Parts," printed in number 59 of Philosophical Transactions in May 1670. ${ }^{73}$ As mentioned above, a letter to Thomas Browne of 18/28 February 1669 contained information about the baths of Buda, much of which was ultimately included in the printed account. However, instead of sending a tidied version of the original letter, Edward rewrote the account using a selection of his own letters, which Thomas had "writ out into a booke" while he was away. ${ }^{74}$ Thomas Browne once more intervened in this process, though most of his suggestions amend the language rather than the substance of the account. ${ }^{75}$ The account that was eventually sent to the Society, written in Edward's fair hand, almost always adopts Thomas's suggestions. ${ }^{76}$ Besides the more superficial editing, Thomas also contributed to the account's arrangement of information. Edward's rewriting of disparate letters and notes into one single account creates a panoptic report of the totality of his experiences of the baths of Europe: it is not an account of a single event (like, for instance, those written by Boyle, which generally provide a report of "how, in one instance, the world had behaved") but a more wide-ranging analysis. ${ }^{77}$ On the final page of Edward's draft of the account of the baths, which describes Glasshitten and Eisenbach, Thomas Browne has added a note stating that "After this follow the Baths of Buda." 78 The printed account adopts this suggestion, moving from the description of Eisenbach to that of Buda. As Edward had requested back in April 1669, Thomas was helping him "to range" his accounts, shuffling and rearranging information to create a methodical narrative progression through the baths of Europe that fit—in this case — the Society's approved methods of reporting as instantiated in the heads and queries. ${ }^{79}$

Travel Literature and the Evolution of the Novel (Lexington: University Press of Kentucky, 1983); and Kristen Sandrock, "Truth and Lying in Early Modern Travel Narratives: Coryat's Crudities, Lithgow's Totall Discourse and Generic Change,” European Journal of English Studies 19 (2015): 189-203.

${ }^{72}$ BL Sloane MS 1847, 166r.

${ }^{73}$ The letter that this account was printed from was read to the Society on 17 February 1670.

${ }^{74}$ BL Sloane MS 1847, 52v.

75 "Accidence" rather than "substance," to use Marchitello's terms (Narrative and Meaning, 42). The drafts of this account are found in BL Sloane MSS 1911-13, 148r-150v and 161r-162r.

${ }^{76}$ Royal Society EL/B1/144.

${ }^{77}$ Peter Dear, "Totius in verba: Rhetoric and Authority in the Early Royal Society," Isis 76 (1985): 152.

${ }^{78}$ BL Sloane MSS 1911-13, 162r.

${ }^{79}$ Here, for instance, Edward describes all of the baths and mineral waters - per Boyle's third head-before describing the quarries, mentioned at the end of Boyle's fourth head (Boyle, "General Heads," 187 and 189). 
After systematically describing the baths and then the quarries of Europe, Edward's account concludes with a more curious story about Mount Olympus in Larissa, which Edward noted first in his journal on 16 September $1669 .{ }^{80} \mathrm{In}$ the draft of the article, this story is added in Thomas Browne's hand. However, though Edward mentioned Mount Olympus in a letter to his father of October 1669, he did not include this story. The fact that it is recorded only in note form in Edward's journal suggests either that Edward Browne wrote up the story once home and that Thomas Browne specifically earmarked it for inclusion in this account, transcribing a now-lost copy of Edward's original here, or possibly that Thomas Browne wrote the section himself based on his son's oral relations. Either way, its inclusion here is enacted via Thomas's hand, rather than Edward's. This reflects Thomas's earlier inclusion of the story of "the firing of Chremnitz mine by a boy" in the account he had edited for the Society while Edward was still away. ${ }^{81}$ Once more, Thomas encourages Edward to report not just objective observations of a place, but stories from it.

Even once at home, then, Edward did not write his accounts as a lone author; his father's hand presents itself throughout drafts of the three 1670 articles, and almost all of his suggestions are enacted in the versions sent to the Society. Though the Society prided itself on the reliability of its findings, these articles were composed with the help of Thomas Browne, who was pointedly not a member of the Society. ${ }^{82}$ Just as kinship networks transferred and interfered in Edward's foreign correspondence, they are likewise in evidence in accounts composed at home. Though the Society encouraged cooperation in the pursuit of knowledge, this is perhaps not the kind of cooperation that they envisaged: if anything, the presence of an untraveled hand in travel accounts dilutes the authenticity of the accounts that ultimately contributed to the Society's repository of knowledge and to the Philosophical Transactions.

While Thomas Browne's voice is the most frequent interpolation in Edward's works, it is not the only one. On several occasions, Edward's own testimony gives way to someone else's. For example, in his general account of Hungary, Edward includes an account about a salt mine at Eperies (Eperjes) that was given to him by the brother of his landlord at Vienna, Mr. Beck. ${ }^{83}$ In a letter to his father of 2 May 1669, Edward notes that he "met the Conte Rothal who was sent to treate with Abassi or his officers at Cascahu [Kosice, Hungary] or farther up nigher Transilvania. I desired Mr Becks brother who waiteth upon him to get me a description of the salt-mines and other rarities in those countreys." ${ }^{\circ 4}$ Here, we see Edward utilizing his local networks to procure further knowledge for the Royal Society. This, in and of itself, is not unusual: as Steven Shapin notes, "the category of 'experience' customarily and justifiably encompassed not just what individuals had by way of their own sense but also the

\footnotetext{
${ }^{80}$ BL Sloane MS 1905, 16v-17r. This story records that "there was a spring of whitish water upon that Hill, which was drank of by many persons in their great heat and thirst, contracted by ascending the mountain, but proved very destructive unto them in 3 dayes, they then complayning of an heaviness and coldness of their Stomacks till they dyed" (Browne, "Baths of Austria and Hungary," 1051).

${ }^{81}$ Bodleian Rawlinson D MS 108, 48r.

${ }^{82}$ Steven Shapin suggests that "what underwrote assent to knowledge claims was the word of a gentleman, the conventions regulating access to a gentleman's house, and the social relations within it." While Thomas Browne was undoubtedly a gentleman, he never situated himself within the Society's spatial or social realms as his son did, placing him on the liminal edges of the Society. In turn, he was an unverified reporter, as it were. See "The House of Experiment in Seventeenth-Century England," Isis 79(1988): 404.

${ }^{83}$ Browne, "Directions and Inquiries," 1192-93.

${ }^{84}$ BL Sloane MSS 1911-13, 29v.
} 
reliable testimony they had of others' sensory engagements with the world." 85 However, in the general account that Edward sent to the Society — which includes the reported accountthe story has been edited a little. The key change is that Edward chooses to minimize the familiar nature of this knowledge exchange. Instead of acknowledging that it was a pragmatic connection forged from the practicalities of travel that led to the gathering of information in this instance, Edward plays up the gentlemanly relationships involved. Instead of a named personal acquaintance asked to gather information about his destination, the Society account mentions only "some of [Rothal's] attendants": Beck becomes simultaneously pluralized and homogenized, placed in the service of a superior and denied his own agency. ${ }^{86}$ Beck supported Edward's investigative endeavors once more in October, when Edward saw "Conte Rothal's house newly built and painted very well. Mr Becks brother shew me it and gave me also a peece of yellow amber colour stonesalt out of the mine from Eperies." 87 However, in much the same way that Beck's identity was elided in the first instance, the account edited for the Society again redacts his involvement, merely noting that "Count Rothal hath a large piece of [stonesalt of] a fair yellow." ${ }^{88}$ In this example, Edward elides the networks behind his acquisition of knowledge, just as the family interventions into Edward's articles are largely silent in the printed versions.

In other instances, Oldenburg excised pieces of information included in Edward's letter when he printed the accounts. For example, Edward's original account of the baths records the reason for the locals calling "Cuzzoculige" the "bath of the saint"; Edward records that "a Turkish saint went into this bath laying the words of the great Prophet upon his breast, and there diing, his body did not sinke, nor were the writings wet." 89 Oldenburg removes this story, noting only that it is called "the Bath of the Saint; for which name the Turks give a superstitious reason." 90 At the same bath, Edward reports that he gave the monks who tend to it "a small gratuity \& they treated me with fruites and a water melon"; once more, Oldenburg omits this, noting only that the monks take care of the saint's bath. ${ }^{91}$ All of this supports the Royal Society's aim of focusing exclusively on accounts of natural phenomena rather than on religion, politics, and storytelling. As Jason H. Pearl highlights, "lost in the 'General Heads"'-Boyle's directions to travelers_-"are native inhabitants, downgraded to the status of all the other topics." 92 Here, it seems that the inhabitants, such as the monks and the Turks whose story is dismissed as superstition, are more than downgraded; they are redacted

\footnotetext{
${ }^{85}$ Shapin, A Social History of Truth: Civility and Science in Seventeenth-Century England (Chicago, IL: Chicago University Press, 1994), 202-3.

${ }^{86}$ Much as Royal Society experiments were shown communally to avoid "misperceptions on the part of the individual observer," here the collective nature of the attendants' reporting validates it: Kathleen Crowther, "The Scientific Revolution," in The Oxford Handbook of Early Modern European History, 1350-1750, Vol. 2, ed. Hamish Scott (Oxford: Oxford UP, 2015), 60. Further, Atkinson highlights that "early modern scientists and their apologists traded on [the]] conventional social image of the gentleman for rhetorical purposes. In so doing, they hoped to gain for themselves its special claims to authority, disinterestedness, and more rectitude": Dwight Atkinson, "The 'Philosophical Transactions of the Royal Society of London,' 1675-1975: A Sociohistorical Discourse Analysis," Language in Society 25, no. 3 (1996): 362.

${ }^{87}$ BL Sloane MSS 1911-13, 53v.

${ }^{88}$ Browne, "Mines, Minerals, Baths," 1193.

${ }^{89}$ Royal Society EL/B1/144.

${ }^{90}$ Browne, "Baths of Austria and Hungary," 1049.

${ }^{91}$ Royal Society EL/B1/144; and Browne, "Baths of Austria and Hungary," 1049.

92 Pearl, "Geography and Authority," 75.
} 
altogether. While this was Society protocol, it nonetheless highlights Oldenburg once more editing Edward's accounts to support the intentions and house style of the Society and the Transactions: even though the reporting style is on brand, Edward's topics, on occasion, wander off course. ${ }^{93}$

Oldenburg furthermore edited the order of the articles. For instance, though Edward's account of the salt mines and the metal mines were sent as two distinct letters, they were printed in the Philosophical Transactions together, alongside the list of queries sent to Edward. ${ }^{94}$ In addition, Oldenburg extracted a section on copper mines at Herrngrundt and published that as a standalone article without the relevant accompanying query. ${ }^{95}$ At the end of the compiled article on the salt, silver, and gold mines in number 58 of the Transactions, Oldenburg inserts what seems to be an advertisement to the reader, noting that "So far this generous Travailer of the Hungarian Gold- and Silver-mines: what he hath observed concerning the Copper-mines, and the Baths in those parts, we must referr to the next opportunity." 96 Sure enough, the next issue of the Philosophical Transactions, number 59, includes two more of Edward's accounts: the extracted section on Herrngrundt and the account of the baths (which was read to the Society on 17 February 1670). While it does not really matter, in a sense, that these articles were reordered-because they all act independently of one another just as well as they do in a sequence- this draws attention to Oldenburg's role as editor. Oldenburg's choice to nod toward Edward's other accounts without printing them here places him in a position of authority: Oldenburg ensured that readers knew that he controlled the Transactions, while simultaneously drawing attention to the vast quantity of information that many investigators regularly entrusted to him. As Maurizio Gotti has noted, "Oldenburg's role as the centre of this correspondence network was not at all neutral"; here, we can extend Gotti's argument to apply to Oldenburg's role at the center of the Philosophical Transactions, in which he did more than neutrally share accounts that had been sent him. ${ }^{97}$

It was not, then, just Edward and his father who edited the accounts from the more comfortable climes of England. Oldenburg too made minor changes to both the content and the order of the information sent him by Edward, in order to curate the specific kind of scientific journal that he envisaged.

\section{REASSESSING THE RELATIONS: COLLABORATION AND COOPERATION}

This case study, with its various complexities of authenticity, authorship, and publication, has three key implications. The first relates to authorship models within the Philosophical

\footnotetext{
${ }^{93}$ For more on Oldenburg as editor, see Moxham, "Form and Genre in the Philosophical Transactions."

${ }^{94}$ These letters were sent on 5 February 1670 and 8 March 1670, respectively.

${ }^{95}$ Edward's original materials follow the order: salt mines (in one letter of 5 February 1669); the gold mines at Chremnitz; the copper mines at Herrngrundt; and the silver mines at Schemnitz. These last three accounts were sent together in a single letter of 8 March 1670. The printed article is ordered as follows: list of queries sent to Browne at Vienna; the account of the salt mines; the account of the gold mine at Chremnitz; and an account of the silver mines of Schemnitz. The account of the copper mines at Herrngrundt was published separately.

${ }^{96}$ Browne, "Directions and Inquiries," 1196.

${ }^{97}$ Gotti, "Scientific Interaction," 156.
} 
Transactions, the second to Thomas Browne's own epistemological principles, and the third to the importance of familial networks and, more specifically, the Brownes as collaborators.

The Royal Society has been described as a "cooperative endeavor," and that is true insofar as investigators worked together to produce an exponentially growing range of knowledge. ${ }^{98}$ All Society members, simply by engaging willingly with the aims espoused at the Society's inception, cooperated to further its ends: "to make faithful Records, of all the Works of Nature, or Art, which can come within their reach . . . to restore Truths . . . and to make the way more passable, to what remains unreveal'd." 99 However, "cooperation in the work itself was not part of this ideal": similarly, "authorship itself was to be ascribed to individuals." 100 Despite the cooperative aims of the Society, individualism was a key component of its success, and many members worked as virtuosos rather than as groups of coinvestigators on single projects. ${ }^{101}$ However, ascription of singular authorship to any given work is by no means a guarantee of writerly independence. From the foregoing study it has become clear that, certainly in some instances, collaboration underpinned not just the broad creation of knowledge but the specific writing of knowledge. Indeed, Edward Browne's case reverses what Alan G. Gross, Joseph E. Harmon, and Michael S. Reidy consider "a consensus among scholars" that "a scientific fact was an occurrence in the natural world that was reported by a reliable individual — usually a member of a scientific society — and was witnessed by one or more such observers." ${ }^{102}$ Edward's "facts," touted by the Society, were witnessed by himself (or a secondary reporter) alone, but depend on multiple (hidden) reporters who were not part of a scientific society. Edward's collaborative model of authorship inverts our expectations of Society reportage. ${ }^{103}$

This brings us to Thomas Browne. We have seen that many of Thomas's interpolations to Edward's articles were largely superficial, but in some more complex interventions he inserts material taken from archives of letters and-in the case of the foreign correspondence - has unchecked editorial control over an article. He is, in one sense, collaborating with Edward here, but much of the work he carries out places him as an executive editor or even an agent. Either way, Edward's work was the product of extensive collaboration. Thomas repeatedly attempts to widen the range of information in his son's work: when Thomas suggests that Edward include a story from a different part of Europe as

\footnotetext{
${ }^{98}$ Dear, "Totius in verba," 147.

${ }^{99}$ Thomas Sprat, The History of the Royal-Society of London for the improving of natural knowledge (London, 1667), 61.

100 Dear, "Totius in verba," 147; and Johns, "Reading and Experiment," 249. In contrast to Dear, Johns notes that "experiments were necessarily collective," pointing towards the disjuncture between individualism and collectivism/cooperation within Society practices.

${ }^{101}$ For a detailed study of an early modern collaborative work, see Elizabeth Yale, Sociable Knowledge: Natural History and the Nation in Early Modern Britain (Philadelphia: University of Pennsylvania Press, 2015), particularly chap. 4, "John Aubrey's Naturall Historie of Wiltshire: A Case Study in Scribal Collaboration." 102 Gross, Harmon, and Reidy, "Argument and 17th-Century Science: A Rhetorical Analysis with Sociological Implications," in Rhetoric and the Early Royal Society: A Sourcebook, ed. Tina Skouen and Ryan J. Stark (Leiden: Brill, 2014), 133.

${ }^{103}$ Heather Hirschfeld has highlighted the tendency for scholars to use the term collaboration "to discuss not a precise mode or form of composition and publication but the general nature of literary production and consumption" ("Early Modern Collaboration and Theories of Authorship," PMLA 116 [2001]: 610). Here, I narrow the Oxford English Dictionary's definition of the term to mean not just "united labour" but "united labour on a single project" (OED Online, s.v. "collaboration, n.”).
} 
an addendum to an account, or when he helps Edward to compile all of the reports about baths into one account (rather than submitting each location's findings as a distinct article), he takes a panoptic overview of Edward's journey and findings. Likewise, the fact that all of the articles on gold, silver, and copper mines are edited together in Sloane MSS 1911-13 suggests that Browne's instinct was to portray Edward's knowledge and experience as an interwoven whole, rather than as discrete occurrences. This conforms with his later interventions into Edward's publishing career. In June 1670, Thomas recommended that Edward publish a book of his travels, instructing him to "thinck of historicall and narrative observations concerning your last traveyles ... sett them downe \& not lette all passe in silence concerning countries travaylled by so fewe." 104 Over a year later, Thomas recommended that Edward use his Transactions articles to help create the book, adding that Edward should add "anything unto them, as the story of the man that putt a snakes head into his mouth in the bath, $\&$ of the Hussar wch bathd in a frost at midnight $\&$ for the mines you need not bee so particular as to give the full account of preparing the metalls in this narration, butt how you went in, how deep \& what you observed \&c."105 These are not merely superficial adjustments, but instructions on how to write: this book was envisaged not as an experimental account but as a narrative report of the traveler's experiences.

Furthermore, the draft of Edward's second published book, the 1677 Account of several travels through Germany, exists only in Thomas's autograph. ${ }^{106}$ Thomas created his own full draft of this work, seemingly specifically for editorial purposes. Arno Löffler has noted that Thomas's interventions here are largely superficial, commenting that Thomas's "activity as an editor is limited mainly to the addition of epithets." ${ }^{107}$ However, Thomas's activities extend beyond that. In this draft, for instance, we see Edward's copy-text include some verses in German. On the facing verso page, Thomas notes that "these verses would bee englished in verse or prose"; at a later date, Edward has inserted an English translation of the verses above Thomas's note and crossed the suggestion out, marking it as completed. ${ }^{108}$ The two worked in tandem on these publications, as they did on the articles, and much work that we consider to be "by" Edward Browne may, in fact, prove to be the work of Thomas too. Though it is clear that Thomas was an inveterate tinkerer-offering small-scale suggestions both on Edward's work and on his own, as his 1672 annotated copy of Pseudodoxia Epidemica attests - those were not his only marks. ${ }^{109}$ Across Thomas Browne's entire oeuvre, and into his son's, he aims to present an entire story. Just as Thomas professes in Religio Medici that "our estranged and divided ashes shall unite againe," the substantive work he carries out on behalf of his son, and encourages his son to take on himself, unites the travels,

\footnotetext{
104 BL Sloane MS 1847, 55r.

${ }^{105}$ Ibid., 169v. The story of the hussar appears on page 87 of Edward's Brief Account. Thomas's recommendation to include such stories, which address local custom or curiosities, in the books highlights that they were generally deemed unsuitable for the articles.

106 BL Sloane MS 1879 and BL Sloane MS 1855.

${ }^{107}$ Löffler, "Sir Thomas Browne als Redaktor von Edward Browne’s Travels," Anglia 88 (1970): 337-40 (my translation). Löffler suggests that Thomas may have edited other parts of the travels, as well as the Vienna treasury he analyzes here, but comments that we cannot "certainly prove" as much: however, other manuscripts - such as BL Sloane MS 1855-do prove as much.

${ }^{108}$ BL Sloane MS 1855, 44v-45r.

${ }^{109}$ Browne's annotated copy of Pseudodoxia Epidemica (London, 1672) is held in the Norfolk Heritage Centre at the Norwich Millennium Library, call number C828 BRO.
} 
aiming to portray its entirety, pilgrimages and all. ${ }^{110}$ Edward's work even adopts Thomas's own tendency to reproduce others' knowledge in his work without ascription: as the authors Thomas cites remain invisible contributors to his own works, Thomas remains an invisible contributor in his son's works. ${ }^{111}$ For Thomas, knowledge making is not about ascription and recognition. Indeed, he declares himself "Ready to be swallowed in any worthy enlarger: as having acquired our end, if any way, or under any name we may obtain a work, so much desired, and yet desiderated of Truth." 112

Finally, we must look to the familial networks behind Edward's works. Clearly, Thomas Browne's influence was central to Edward's work, but he was not the only family member involved. Rather, the Browne family network emerges as integral to Edward's entire project: Edward sent his letters to his sister, Anne, in London, who passed them to their father, Thomas, at Norwich, who compiled them into fair copies and furthermore asked his daughter, Elizabeth Lyttelton, to produce fair copies of Edward's drawings. ${ }^{113}$ How many other investigators and authors who appear at first glance to have written their works independently were involved in various familial exchanges throughout the production of their works? We know now, for instance, that "to maintain as much 'creative control' over his work and its publication as possible," the physician Martin Lister (1639-1712) "taught his two daughters, Susanna . . . and Anna ... how to limn and engrave images." 114 Similarly, the naturalist Maria Sibylla Merian's (1647-1717) "legacy was kept alive by her two daughters . . . who continued her editorial and artistic work after her death." 115 As Oded Rabinovitch argued recently, beyond the physical act of writing, "ideas about authorship have suffered because of the failure to consider the part played by kinship and its relation to a range of categories, from informal patronage ties to office holding and membership in formal institutions." 116 In Edward Browne's case, it is not just the Transactions articles and his printed works that bear the quiet insignia of his family: a multitude of pictures from his travels are preserved in Add. MS 5233, and may have been drawn by Lyttelton before being inscribed with Thomas Browne's copies of Edward's letter-text; a letter sent from Lyttelton to Edward at London enclosed two pictures of a stork given to her father, which Lyttelton had drawn following her father's observations of the bird; in a later interaction with the Royal

\footnotetext{
${ }^{110}$ Browne, Religio Medici (London, 1643), 1.46.

${ }^{111}$ Jeremiah Finch, for instance, discusses Browne's extensive "pilfering" in the first chapter of The Garden of Cyrus ("Sir Thomas Browne and the Quincunx," Studies in Philology 37 [1940]: 274-82). For a discussion of Browne's complex attitude toward "plagiarism," see Stephen Orgel, "Plagiarism Revisited," in his Spectacular Performances: Essays on Theatre, Imagery, Books, and Selves in Early Modern England [Manchester:

Manchester University Press, 2011], 211-28.

112 Browne, "To the Reader," in Pseudodoxia Epidemica (London, 1672).

${ }^{113}$ Brent Nelson draws attention to the "culture of curiosity" in the Browne family, highlighting the shared collecting practices of Edward and Thomas in particular. His essay focuses on habits of collection rather than on the shared literary pursuits of the family. See Nelson, "The Browne Family's Culture of Curiosity," in Sir Thomas Browne: The World Proposed, ed. Reid Barbour and Claire Preston (Oxford: Oxford University Press, 2008), 80-99.

${ }^{114}$ Roos, “Art of Science," 20.

115 Alicia C. Montoya and Rindert Jagersma, "Marketing Maria Sibylla Merian, 1720-1800: Book Auctions, Gender, and Reading Culture in the Dutch Republic," Book History 21 (2018): 62. For more on the familial collaboration, see Ella Reitsma, Maria Sibylla Merian \& Daughters: Women of Art and Science (Amsterdam: Rembrandt House Museum, 2008).

${ }^{116}$ Rabinovitch, The Perraults: A Family of Letters in Early Modern France (Ithaca, NY: Cornell University Press, 2018), 16.
} 
Society, Lyttelton made a fair copy of Edward's account of an ostrich, a version of which was sent to the Society. ${ }^{117}$ The wider family loom large over Edward's entire oeuvre, often as an invisible presence, but always as a vital component of his literary productions.

Given the current relative absence of scholarship on early modern literary familial collaboration, it is difficult to assess how unique or commonplace this case study of Edward and his family is. While Lister's daughters were recruited specifically to support their father's work, and Rabinovitch has shown that the Perrault family in seventeenth-century France shared a strategy for furthering the family's reputation in general, the Brownes' model of collaboration was first precipitated by the contextual nuances of literary production and later carried out by two agents simultaneously on a single work; at times the collaboration was uninvited, and at others actively pursued. This particular form of cooperative literacy has not been heavily investigated, and further research into this developing field is vital if we are to assess whether the Browne family is symptomatic of wider cultures of textual collaboration or a singularity in their communal creative practices. ${ }^{118}$

The evidence set out over the course of this article compels us to reexamine some of the key principles of early modern authorship across the social spectrum. Firstly, it is clear that we must be wary when taking at face value the authorship of knowledge perpetuated by the Royal Society: some accounts might incorporate unacknowledged secondary voices in place of the firsthand observation that the Society so lauded, and others might, unbeknownst to the author, have been edited into a new order or form. Likewise, accounts in the Philosophical Transactions are by no means always the originals of accounts sent to Oldenburg. Despite the Society's early efforts to assure readers of the authenticity of their information, modern scholars should be cautious not to take accounts and letters as original and authentic in all cases. To take the Society's own phrase, "nullius in verba"- take nobody's word for it. This disjuncture between ascription and authorship, and between recommended models and real working models, extends beyond the Philosophical Transactions: the same disconnection can be found in independent publications. We find Thomas Browne in Edward Browne's books, both paleographically and epistemologically, and we find Edward Browne's discoveries, and Lyttelton's editorial efforts, in Thomas's. These networks of authorship are hidden, but they prove vital to our own conceptions of early modern authorship. Only by focusing not just on titular characters, but also on the no less significant familial and kinship networks which surround them, can we come to understand the extent to which the period was "no monopoly, but a community in learning." 119

\author{
Anna Wyatt \\ University of East Anglia
}

\footnotetext{
${ }^{117}$ For Lyttelton's note on the storks, see Bodleian Rawlinson D MS 108, 71r. For Lyttelton's copy of the account of the ostrich, see BL Sloane MSS 1911-13, 175r-176v. Robert Hooke published "An Account of the Dissection of an Oestridge" in Philosophical Collections 5 (1681/2); repr. in Philosophical Collections, Numbers 1-7, London 1679-1682 (New York: Johnson Reprint, 1965), 147.

118 See Hirschfeld, "Early Modern Collaboration," for a discussion of studies of early modern collaboration. Hirschfeld's article highlights the prominence of studies of theatrical collaboration in comparison to studies of collaborative practices in other genres.

119 Thomas Browne, Religio Medici, 2.3.
} 


\section{Appendix A}

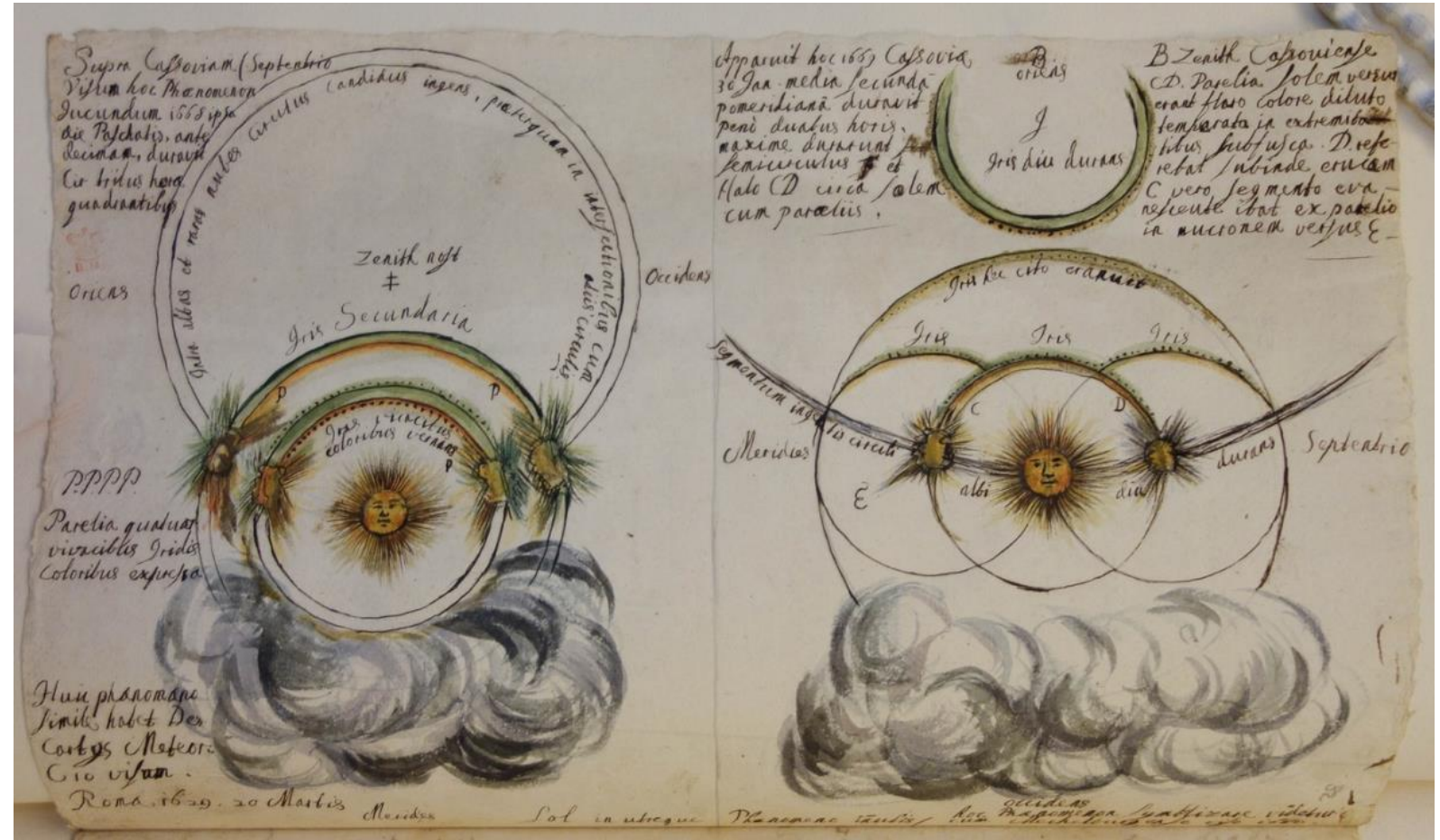

Lyttelton's copy of the parhelia (British Library, Add MS 5233, fol. 32v)

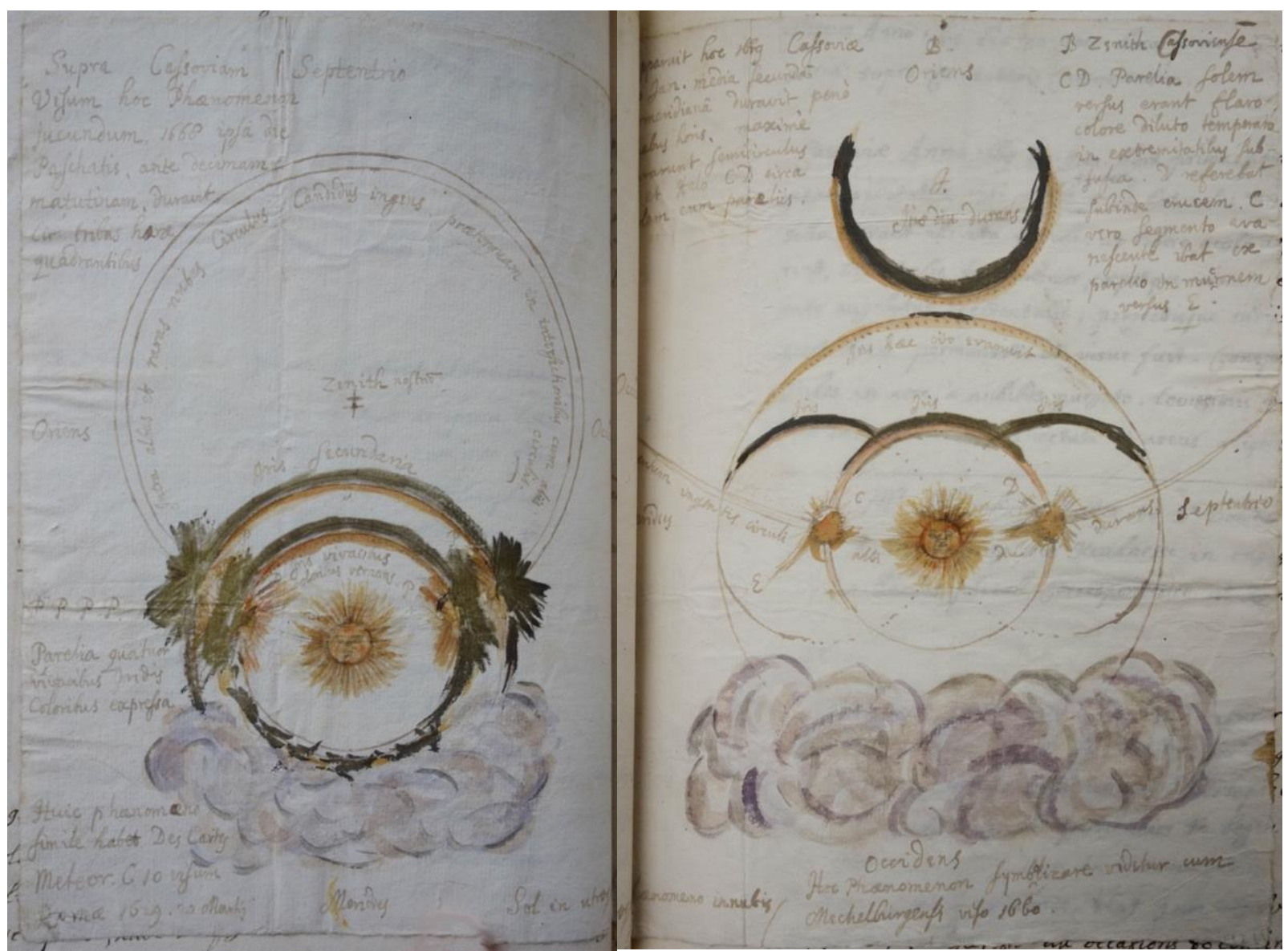


Edward's original of the parhelia (Royal Society LB0/3, fols.34-35).

Appendix B

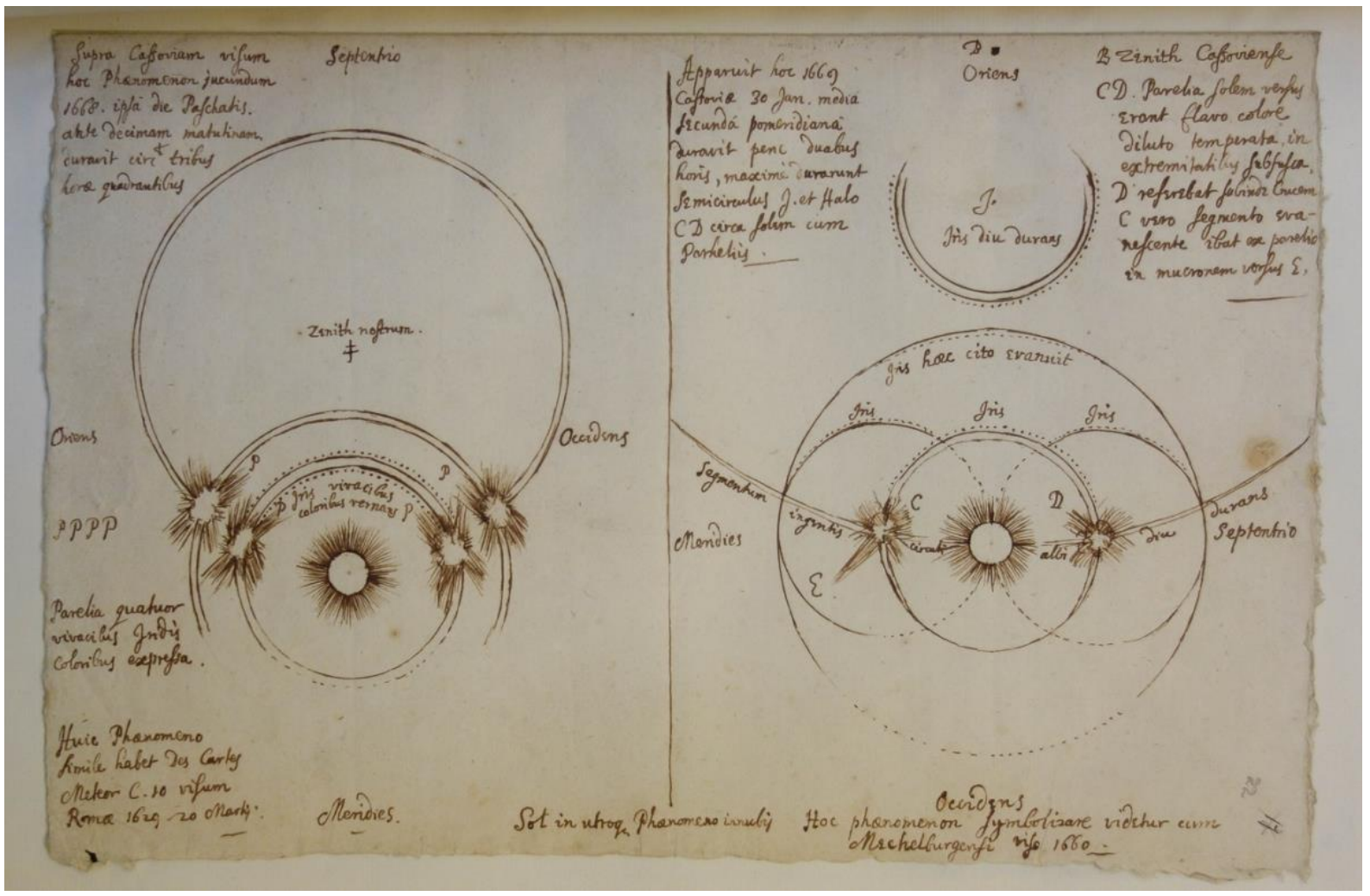

Edward's copy of the parhelia (British Library, Add MS 5233, fol. 22r). 